\title{
Conformational flexibility of interdomain linker in bovine tyrosyl-tRNA synthetase studied by molecular dynamics simulation
}

\author{
N. A. Pydiura, F. A. Tereshchenko, A. I. Kornelyuk \\ Institute of Molecular Biology and Genetics, National Academy of Sciences of Ukraine \\ 150, Acad. Zabolotny Str., Kyiv, 03143, Ukraine \\ kornelyuk@imbg.org.ua
}

\begin{abstract}
Here we report a study of molecular dynamics of a YCD2 fragment of mammalian tyrosyl-tRNA synthethase (Asp322-Ser528), which includes the COOH-terminal cytokine-like domain, intermodular flexible linker, and H5-a-helix of catalytic core of synthetase. Our calculations show that while compact $C$-terminal domain was less flexible and relatively stable, the interdomain linker shows a high degree of conformational changes. After short relaxation time it forms a short helix-like structure, which may be involved in the regulation of domain interaction and modulation of protein activities.
\end{abstract}

Keywords: tyrosyl-tRNA synthetase, cytokine, C-module, molecular dynamics, linker flexibility.

Introduction. Bovine (Bos taurus) tyrosyl-tRNA synthetase (TyrRS, EC 6.1.1.1) is one of the most studied mammalian aminoacyl-tRNA synthetases [1]. So far, the full-length synthetase has not been crystallized and its experimental 3D structure has not been reported. Difficulties of obtaining crystals can be caused by presence of a labile peptide linker between $\mathrm{N}$-terminal catalytic core and C-terminal domain. Mobility and flexibility of this linker may be required for adaptable orientation of domains necessary for tRNA aminoacylation reaction. The lack of experimentally determined structure justifies the use of computational methods for the study of TyrRS spatial composition and temporal behavior. Hence, the main aim of this work is to study the structure of interdomain linker and its conformational flexibility using molecular dynamics (MD) simulation techniques.

Bovine TyrRS exists as a homodimer formed by two $59.2 \mathrm{kDa}$ subunits of 528 amino acid residues (C) N. A. PYDIGRA, F. A. TERESHCHENKO, A. I. KORNELYUK, each. N-terminal catalytic core and C-terminal domain of a subunit are joined by a peptide linker (Fig. 1). N-terminal module forms a minimal $39 \mathrm{kDa}$ TyrRS which reveals full catalytic activity in vitro $[1$, 2]. C-terminal domain is dispensable for catalytic activity of mammalian TyrRS [3]. Presence of this domain is not a ubiquitous feature among TyrRSs. Up to date, it is found in human, mouse, rat, zebra fish, and fruit fly. There is no equivalent of $\mathrm{C}$-domain in TyrRS of invertebrates (nematode Caenorhabditis elegans), plants, lower eukaryotes, and Archaebacteriae. This suggests that it has been attached to the TyrRS of chordates and insects common ancestor later in cvolution. TyrRSs from Eubacteriac have similar composition, but their C-terminal domains have little or no homology to their counterpart in higher eukaryotes or insects, and probably emerged as a result of evolutionary convergence [4]. A multiple alignment of C-domains guided by predicted secondary structure revealed two independent sub-domains [3]: a $\beta$-pleated part (OB-fold, residues Val363- 
PYDIURA N. A. TERESHCHENKO F. A., KORNELYUK A. I

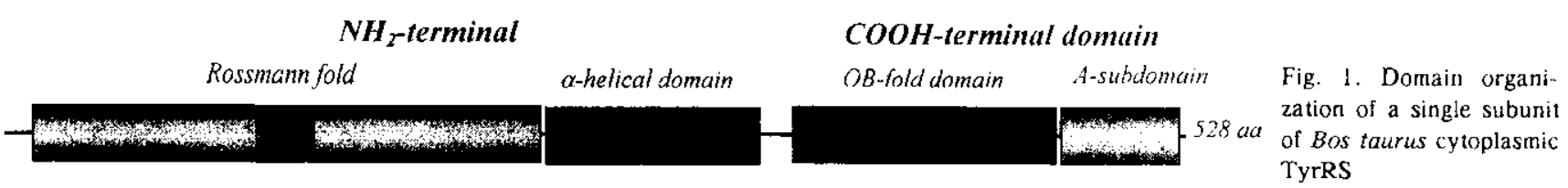

Lys 470) and an $\alpha$-helical A-subdomain (residues Gly471-Ser528, Fig. 1) [3, 5]. The TyrRS C-domain reveals $52.7 \%$ identity to a mammalian cytokine (endothelial and monocyte activating polypeptide, EMAP II) $[6,7]$, which activates both monocytes and endothelial cells - an effect first discovered in chemicals induced cancerogenesis $[8,9]$. EMAP II is a product of p43 (proEMAP II) cleavage. p43 is a non-synthetase protein involved in high-molecular weight multi-tRNA synthetases complex formation in higher eukaryotes [10]. p43 interacts with ArgRS directly and modulates its aminoacylation activity [11]. It has been experimentally shown that stressinduced cleavage of TyrRS by an unknown, possibly thiol protease results in acquisition of cytokine-like activity [12-14]. In vitro experiments show that TyrRS C-domain induces a twofold increase of monocyte chemotaxis and enhancement of human tissue factor expression [12-14]. The described effects of the $\mathrm{C}$-domain are similar to those exhibited by EMAP II cytokine.

Several organisms possess C-terminal domains homologous to that of TyrRS. There are experimental data showing involvement of Arclp (G4pl) from Saccharomyces cerevisiae (55.3\% identity) [15], human p43 (pro-EMAP II) $(62.7 \%$ ) [3], and ARCE from Euplotes octocarinatus (52\%) [16] in nonspecific tRNA binding. These proteins direct tRNA to the active sites of corresponding ARSases [15, 17]. It is possible, that during the evolution C-terminal dcmain was transferred to several diverse proteins involved in translation (such as TyrRS, MetRS, p43, and Arclp) to enable their proper functioning in higher eukaryotes protein synthesis apparatus [3].

Bovine C-domain contributes about $50 \%$ of TyrRS affinity to ribosomal RNAs [18]. This binding has a certain specificity: among others poly $(G)$ had the most inhibitory effect in the reaction of $\mathrm{TRNA}{ }^{\mathrm{Tyr}}$ aminoacylation [18]. In chemical modification experiments TyrRS protected anticodon of $\mathrm{TRNA}^{\mathrm{Tyr}}$ from $\mathrm{N}$-nitroso-N-ethylurea modification. Hence, the anticodon region is involved in $t R \mathrm{NA}^{\mathrm{T} y \mathrm{r}}$ recognition by mammalian TyrRS [19].

Despite all the experimental information gathered up to date, there is no clear understanding of
C-domain and interdomain linker role and mode of action. Significance of its relation to both cytokines and tRNA-binding domains is unclear and needs explanation. The absence of experimentally derived structure and importance of studying the role of eukaryotic cytokines justify computational approach to TyrRS study. In the light of recent theories and observations concerning functions of flexible interdomain linkers [20] we are especially interested in gathering detailed information about temporal behavior of TyrRS linker to make an attempt of understanding its functioning in the whole protein.

Materials and Methods. The amino acid sequence of bovine TyrRS was reported earlier [21, 22] and can be downloaded from Entrez (http://www.ncbi.nlm.nih.gov/entrez/), accession number Q29465. To build the model of the three-dimensional structure of TyrRS we used homology modeling techniques [23]. Earlier, we performed homology modeling of 3D structures of $\mathrm{N}$ - and $\mathrm{C}$-terminal domains of bovine TyrRS separately [5, 24] using two PDB structures (1N3L, $95 \%$ homology and 1NTG_A, $92 \%$ ) as templates. The putative conformation of bovine TyrRS interdomain linker was modeled using the C-Abl tyrosine protein kinase structure (1OPL_A). Its fragment connecting $\mathrm{SH} 2$ and $\mathrm{SH} 3$ domains has an unexpected sequence homology $(57 \%$ homology, $32 \%$ identity) to bovine TyrRS interdomain linker (Fig. 2). The exact modeling procedure of the fulllength bovine TyrRS will be published elsewhere.

For molecular dynamics calculations we employed GROMACS 3.1.4 with GROMOS96 force field [25, 26]. We used a virtual octahedral box. Minimal distance from its walls to the protein molecule was $1.0 \mathrm{~nm}$. The box was filled with $16458 \mathrm{SPC}$-models of water molecules. A total protein charge of +6 was compensated by 38 sodium and 44 chloride ions replacing equal number of water molecules to simulate ionic strength of $0.15 \mathrm{M}$.

Algorithms of steepest descent and conjugated gradient were used to do original minimization of system energy. Minimal energy of $200 \mathrm{~kJ} / \mathrm{mol}$ was attained after 3421 steps. We equilibrated water molecules during 100 ps, while keeping proteins coordinates bound to the box with the aid of ad- 


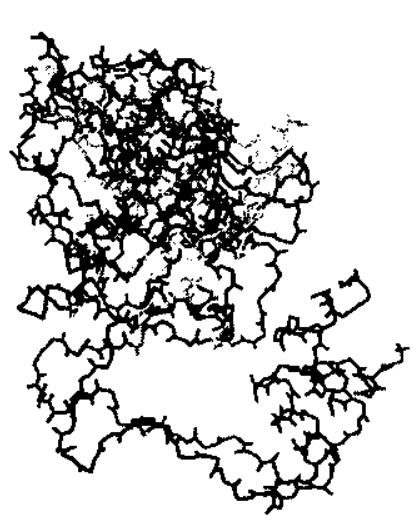

$a$

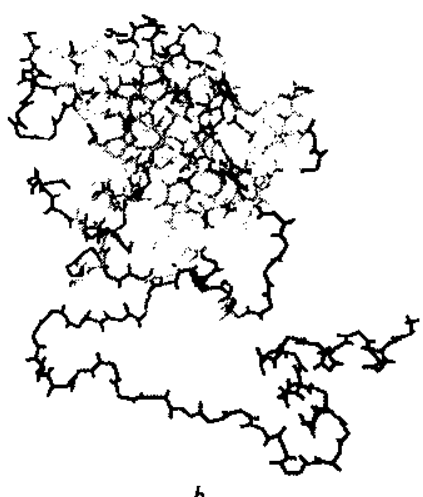

$b$

Fig. 2. Alignment of the YCD2 homology model and the model after 1875 ps of MD. An original model is shown in black, the result of MD is shown in gray: $a-$ alignment of two chains; $b-$ YCD2 after 1875 ps MD colored according to RMSD from the original model. Lesser deviations are marked in gray, higher - in black

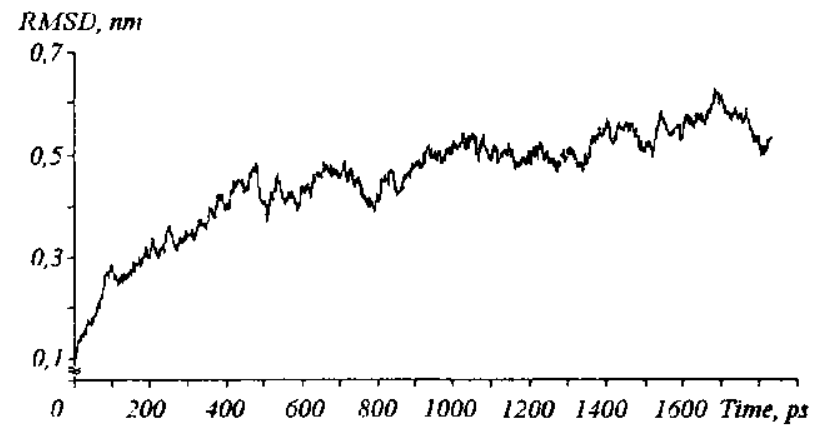

Fig. 3. Time course of RMSD changes (nm) in position of $\mathbf{C}_{a}$-atoms comparing to original model

ditional supplementary harmonic force field. After this procedure we carried out an additional round of energy minimization. An actual modeling procedure was performed for about 2 ns at $27{ }^{\circ} \mathrm{C}(300 \mathrm{~K})$ and resulted in two independent trajectories of 1875 and 2000 ps. We analyzed the obtained results using a suite of standard programs incorporated into GROMACS 3.1.4 package $[25,26]$. A root mean square deviation (RMSD) was calculated by Fit subroutine of Swiss-PDB viewer [27].

Results and Discussion. In order to analyze the conformational fiexibility and temporary structural changes of the interdomain linker, we used MD simulations of the extended cytokine-like C-domain of bovine TyrRS. This fragment, designated as YCD2, has an $a$-helical subdomain of $\mathrm{N}$-terminal catalytic core (residues Asp322-Pro342), the linker region, and complete C-terminal domain. This is not an arbitrary truncation of TyrRS polypeptide chain.

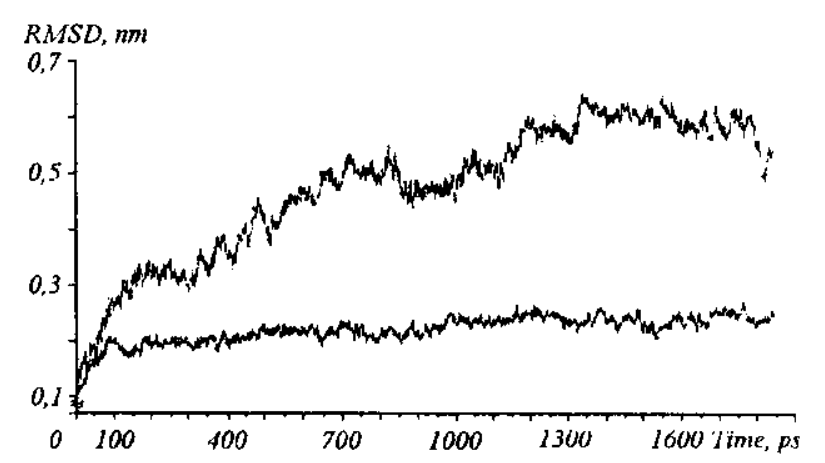

Fig. 4. Time course of RMSD (nm) of the linker area (upper curve), and the remaining part of YCD2 (lower curve)

YCD2 fragment was experimentally obtained earlier as a protein having cytokine-like activities and RNA binding ability [28]. In further discussions we use the numbering system starting from the first amino acid of YCD2, which corresponds to Asp322 of the full length TyrRS. We ran two 1875 and 2000 ps MD simulations, respectively. For further analysis one of them (1875 ps) was selected. Both MD simulation experiments display the same pattern of linker behavior.

Fig. 2 shows an alignment of the initial structure of YCD2 and its structure after 1875 ps of MD simulation. It may be pointed out that both $\mathrm{N}$ terminal fragment and linker region (Pro21-Glu40) are the most flexible and reveal higher deviations from the initial structure.

Fig. 3 represents time course of $\mathrm{C}_{a}$-atoms RMSD. It increased up to $0.4 \mathrm{~nm}$ during first 400 ps quickly. Slower increase during the next 1000 ps brings RMSD to $0.5 \mathrm{~nm}$. After that the system shows low amplitude fluctuations between 0.5 and $0.6 \mathrm{~nm}$. This corresponds to the original re-arrangement and stabilization of the structure, while the last stage reflects small system fluctuations. We suggest that the largest changes are contributed by more flexible linker area. To prove this assumption, we factored out and analyzed RMSD changes contributed by the linker only. The results can be seen in Fig. 4. It is clear that the RMSDs of the area between Aspi (322) and Glu40 (362) (C-terminal part of $\mathrm{N}$-domain and the linker) show higher values (up to $0.6 \mathrm{~nm}$ ) comparing to those of the rest of YCD2 $(0.25 \mathrm{~nm})$. This supports our hypothesis about high impact of the linker on overall protein mobility.

Fig. 5 displays time-dependent behavior of soivent accessible surface area (SASA), as well as its 

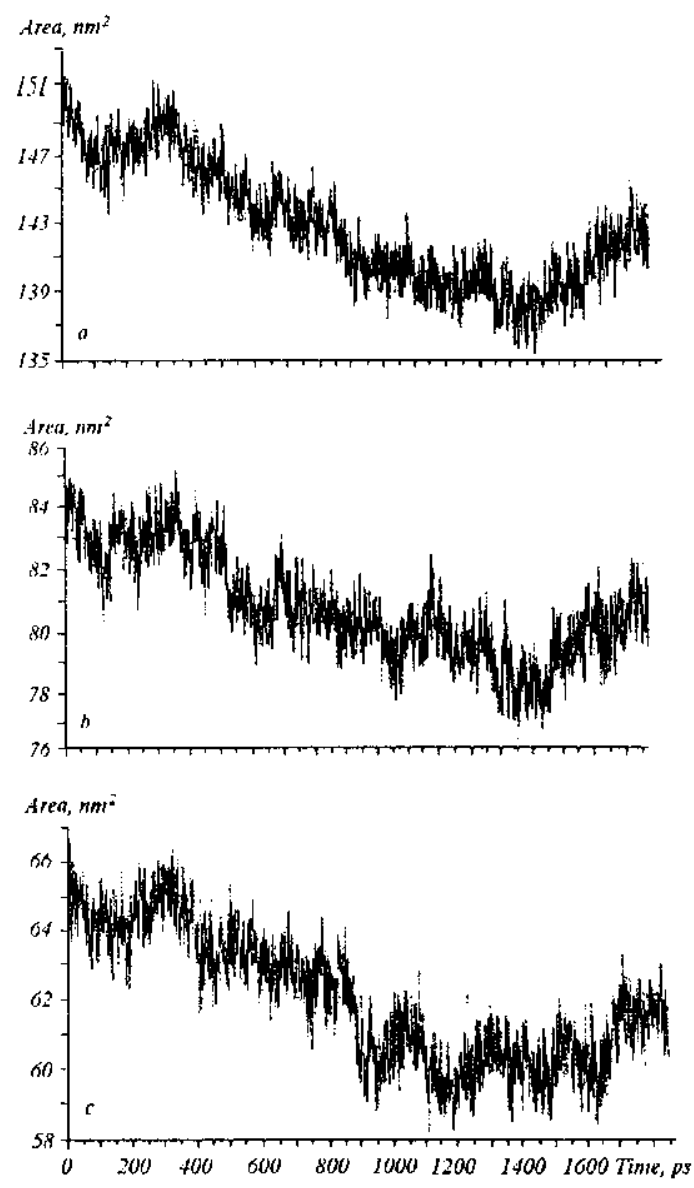

Fig. 5. Time-dependence of total $(a)$, hydrophilic $(b)$ and hydrophobic (c) YCD2 linker surface $\left(\mathrm{nm}^{2}\right.$ ) accessible to solvent

hydrophilic and hydrophobic components. These areas decreased significantly during first $1.5 \mathrm{~ns}$ of the experiment, and then increased by a small amount. This behavior suggests compactization and stabilization of the protein structure in the course of dynamics.

A number of hydrogen bonds formed by protein atoms displays the following trend: it drops after first $50 \mathrm{ps}$ (protein relaxation), and increases significantly by the end of MD trajectory. For the whole YCD2 protein their number drops to 140 , then rises to 155 and later fluctuates around this value (Fig. 6,a). The area Asp21-Val68 (343-389) displays a higher percentwise change comparing to the rest of YCD2 from 18 to 25 (Fig. 6, b). The number of hydrogen bonds is a good indication of secondary structure formation. To get more insight into changes in secondary structure of our protein, we plotted a percentile of time a residue stays in helical conformation (Fig. 7). It is clear, that residues $1-20$
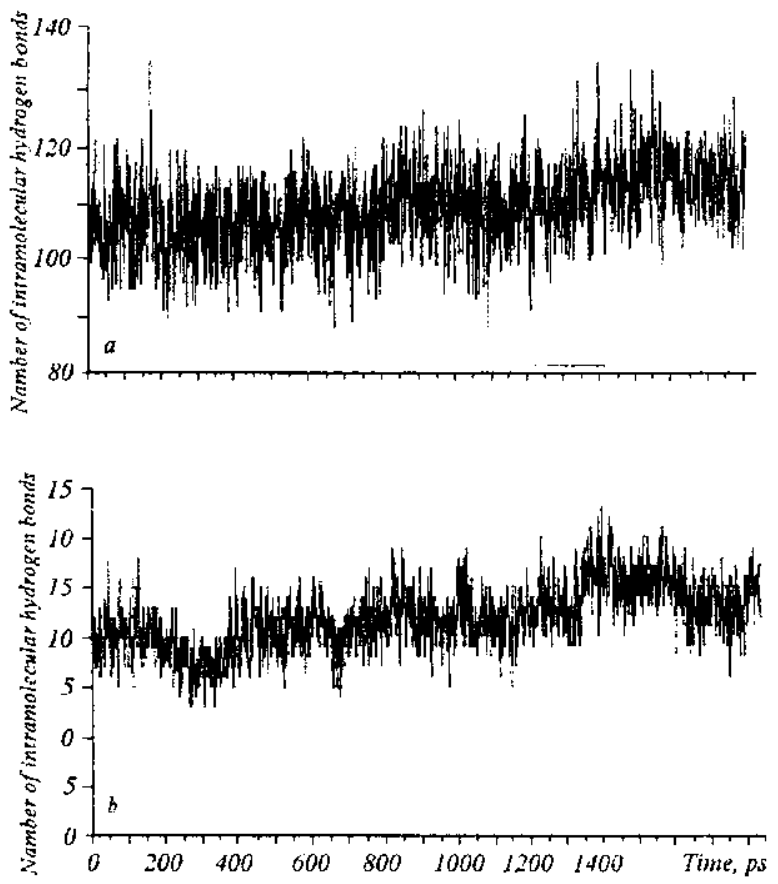

Fig. 6. Change of the number of intramolecular hydrogen bonds versus time (ps): $a-\mathrm{YCD} 2 ; b-$ linker

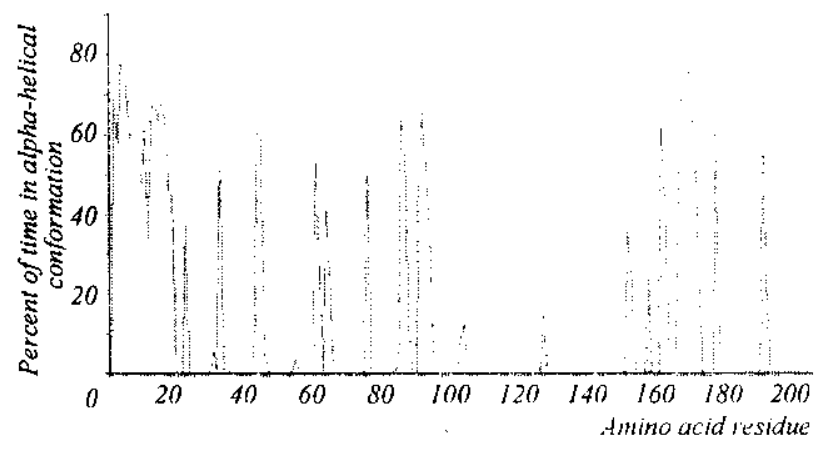

Fig. 7. Percent of time that an amino acid residue stays in helical conformation

which correspond to helical part of $\mathrm{N}$-terminal catalytic module form helices most of the time. Surprisingly, our linker fragment between amino acids 22 (343) and 38 (359) can form unstable helix-like structure.

Analysis of root-mean square fluctuations (RMSF) of $\mathrm{C}_{\alpha}$-atoms, presented in Fig. 8, shows that $\mathrm{N}$-terminal part of YCD2 and the linker area are most labile $(0.3 \mathrm{~nm})$, while $\mathrm{C}$-domain residues remain relatively stable. We think that the linker undergoes compactization as a result of hydrogen bond for- 


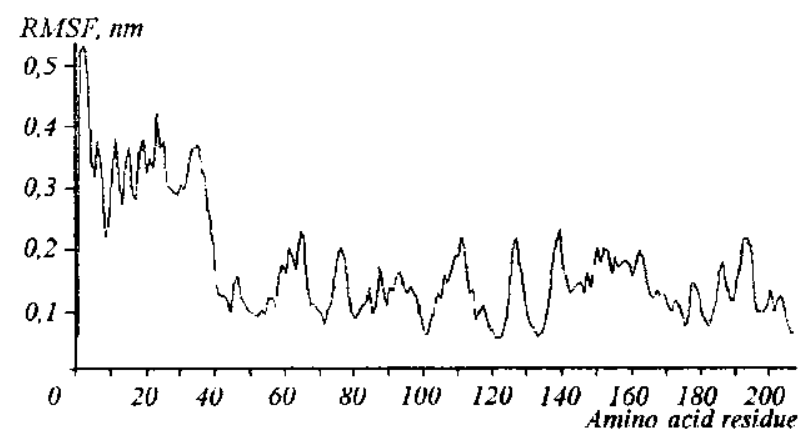

Fig. 8. RMSF (nm) for $\mathrm{C}_{\alpha^{-}}$atoms of $\mathrm{YCD} 2$

mation. This leads to reduction of solvent accessible area.

The peculiarities of linker behavior - change in flexibility by formation of short helical structure may suggest that it may be involved in regulation of TyrRS activity. Such behavior was observed in many proteins, where short interdomain connectors play an important role in function modulation [20]. It is noteworthy that $\mathrm{X}$-ray crystallographic studies of TyrRS from Thermus thermophilus revealed a formation of an additional turn of helix in the flexible linker between $\mathrm{N}$-terminal and $\mathrm{C}$-terminal parts of the enzyme after its binding with cognate $\mathrm{RNA}^{\text {Tyr }}$ [29].

Acknowledgements. This research was supported by grant N 5.07/200 from the Ministry of Science and Education of Ukraine.

\section{М. О. Пидюра, Ф. А. Терещенко, О. І. Корнелюк}

Вивчення конформаційної рухливості міждоменного лінкера тирозил-тРНК синтетазы ссавців методом моделювання молекулярної динаміки

\section{Резюме}

Здійснено досліджения молекулярної динаміки ҮCD2- фрацмента тирозил-тPHК синтетази ссавців (Asp322-Ser528), який включае СООН-кінцевий цитокінподібный модуль, міжмодульний гнучкий лінкер та Н5-а-спіраль каталітичного модуля синтетази. У процесі динаміки компактний С-кінцевий домен виявився мени рухливим $i$ відносно стабільним, тод̈ як міжмодульний лінкер піддався значним конформаційним перебудовам. Після короткого періоду релаксації у лінкері вилвлено формування короткої спіральної ділянки, яка мохе бути причетною до ресуляції взаємодї доменів і модуляції активностей білка.

Ключові слова: тирозил-тРНК синтетаза, цитокін, С-модуль, молекулярна динаміка, конформаційна рухливість лінкера.

\section{Н. А. Пыдюра, Ф. А. Терещенко, А. И. Корнелюк}

Изучение конформационной подвижности междоменного линкера тирозил-гРНК синтетазы млехопитающих методом моделирования молекулярной динамики

Резкме

Описано исследование молекулярной динамики фрагмента YCD2 тирозил-тPHК синтетазы млекопитащих (Asp322Ser528), включающего СООН-концевой цитокинподобный домен, межмодульный гибкий линкер и Н5-а-спираль каталитического модуля синтетазы. $B$ процессе динамики компактный C-концевой домен белка оказался менее подвижным и относительно стабильным, тогда как межмодульный линкер выявил значительные конформационные перестройки. После короткого периода релаксации обнаружено образование короткого спирального участка, который может быть вовлечен в регулирование взаимодействия доменов и модуляции активностей белka.

Ключевые слова: тирозил-тРНК синтетаза, читокин, Cмодуль, молекулярная динамика, конформационная подвижность линкера.

\section{REFERENCES}

1. Kornelyuk A. I. Structural and functional investigation of mammalian tyrosyl-tRNA syntetase // Biopolymers and Cell. 1998.-14, N 4.-P. 349-359.

2. Gnatenko D. V., Kurochkin I. V., Ribkinska T. A., Kornelyuk A. I., Matsuka G. Kh. Purification and characterization of functionally active proteolytically modified form of tyrosy!tRNA synthetase from bovine liver // Ukr. Biokhim. Zhurn.1991.-63, N 4.-P. $61-67$.

3. Levanets $O$. V., Naidenov V. G., Odynets $K$. A., Woodmaska M. I., Matsuka G. Kh., Kornelyuk A. I. Homology of C-terminal non-catalytic domain of mammalian tyrosyl-tRNA synthetase with cytokine EMAP II and non-catalytic domains of methionyl- and phenylalanyl-tRNA synthetases $/ /$ Biopolymers and Cell. -1997.-13, N 6.-P. 474-478.

4. Bedouelle $H$. Recognition of tRNA ${ }^{\text {Tyr }}$ by tyrosyl-tRNA synthetase // Biochimie. $-1990 .-72, N$ 8.-P. 589-598.

5. Golub A. G., Odynets K. A., Nyporko A. Yu., Kornelyuk A. I. 3D structure modeling of the $\mathrm{COOH}$-terminal cytokine-like module of the mammalian cytoplasmic tyrosyl-tRNA synthetase // Biopolymers and Cell. -2000 - 16, N 6.-P. 515-524.

6. Kleeman T. A., Wei D., Simpson $K$. L. First $E$. A. Human tyrosyl-tRNA synthetase shares amino acid sequence homology with a putative cytokine // J. Biol. Chem.-1997.-272.P. $14420-14425$.

7. Kao J., Ryan J., Brett G., Chen J., Shen H., Fan Y. G., Godman G., Familletti P. C., Wang F., Pan Y. C., Stern D., Clauss $M$. Endothelial monocyte-activating polypeptide II. A novel tumor-derived polypeptide that activates host-response mechanisms // J. Biol. Chem.-1992. - 267. -P. 2023920247

8. Kao J., Houck K., Fan Y., Haehnel I., Libutti S. K., Kayton M. L., Grikscheit T., Chabot J., Nowygrod R., Greenberg S., Kuang W.-J., Leung D., Hayward J. R., Kisiel W., Heath M., Brett J., Stern D. $M$. Characterization of a novel tumorderived cytokine. Endothelial monocyte-activating polypeptide Il // J. Biol. Chem.-1994.-269.-P. 25106-25119.

9. Tas $M$. P., Murray J. C. Endothelial monocyte-activating polypeptide II // Int. J. Biochem. Ceil. Biol._1996.-28.-P. $837-841$ 
10. Quevillon S., Agou F., Robinson J. C., Mirande M. The p43 component of the mammalian multi-synthetase complex is likely to be the precursor of the endothelial monocyte-activating polypeptide II cytokine // J. Biol. Chem.-1997.-272.P. 32573-32579.

11. Park S. G., Jung K. H., Lee J. S., Jo Y. J., Motegi H., Kim $S$, Shiba K. Precursor of pro-apoptotic cytokine modulates aminoacylation activity of tRNA synthetase // $\mathrm{J}$. Biol. Chem.1999.-274.-P. 16673-16676.

12. Kornelyuk A. I., Tas M. P. R., Dybrovsky A., Murray C. Cytokine activity of the non-catalytic EMAP-2-like domain of mammalian tyrosyl-tRNA synthetase // Biopolymers and Cell.-1999.-15, N 2.-C. 168-172.

13. Wakasugi K., Schimmel $P$. Two distinct cytokines released from a human aminoacyl-tRNA synthetase // Science.1999.-284.-P. 147-151.

14. Wakasugi K., Schimmel P. Highly differentiated motifs responsible for two cytokine activities of a split human tRNA synthetase // J. Biol. Chem.-1999.-274.-P. 2315523159.

15. Simos G., Sauer A., Fasiolo F., Hurt E. C. A conserved domain within Arclp delivers tRNA to aminoacyl-tRNA synthetases // Mol. Cell.-1998-1 - -P. 235-242.

16. Tan M., Heckmann K., Brunen-Nieweler C. The micronuclear gene encoding a putative aminoacyl-tRNA synthetase cofactor of the ciliate Euplotes octocarinatus is interrupted by two sequences that are removed during macronuclear development // Gene.-1999.-233.-P. 131-140.

17. Simos G., Segref A., Fasiolo F., Hellmuth K., Shevchenko A., Mann M., Hurt E. C. The yeast protein Arc1p binds to tRNA and functions as a cofactor for the methionyl- and glutamyltRNA synthetases // EMBO J.-1996.-15.-P. 5437-5448

18. Kurochkin I. V., Kornelyuk A. I., Matsuka G. Kh. Interaction of eukaryotic tyrosyi-tRNA synthetases with high molecular weight RNAs // Mol. Biol.-1991-25. $\rightarrow$ P. 779-786.

19. Kalachnyuk L. G., Kornelyuk O. I., Matsuka G. K. Tyrosine tRNA from bovine liver. Identification of its interaction sites with homologous aminoacyl-tRNA synthetase by the method of chemical modification // Ukr. Biokhim. Zhurn.-1995.-67, N 5.-P. $60-65$.
20. Wriggers W., Chakravarty S., Jennings $P . A$. Control of protein functional dynamics by peptide linkers // Biopolymers (Pept. Sci.).-2005,-80_-P. 736--746.

21. Levanets O. V., Naydenov V. G., Woodmaska M. I., Odynets K. A., Matsuka G. Kh., Kornelyuk A. I. PCR-amplification, cloning and sequencing of cDNA fragment, encoding a nucleotide binding domain of mammalian tyrosyl-tRNA synthetase // Biopolymers and Cell.--1996.-12, N 5.-P. 66-71.

22. Levanets O. V., Naidenov V. G., Woodmaska M. I., Matsuka G. H., Kornelyuk A. I. Cloning of cDNA encoding C-termina! part of mammalian tyrosyl-tRNA synthetase using of PCRamplified radioactive probe // Biopolymers and Cell. - 1997.13, N 2.-P. 121-127.

23. Elofsson A., Fischer D., Rice D. W., Le Grand S. $M$., Eisenberg $D$. A study of combined structure/sequence profiles // Fold Des. -1996.-1.-P. 451-461.

24. Odynets K. A., Bazylevskyi O. E., Kornelyuk O. I. Homology modeling of structure of $\mathrm{NH}_{2}$-terminal module of mammalian (Bos taurus) tyrosyl-tRNA synthetase // Biopolymers and Cell.-2002.-18, N 6.-P. 547-550.

25. Lindhal E., Hess B., van der Spoel D. Gromacs 3.0: A package for molecular simulation and trajectory analysis // $\mathrm{J}$. Mol. Mod.-2001.-7.-P. 306-317.

26. Van der Spoel D., Lindhal E., Hess B., Groenhof G., Mark A. $E$., Berendsen $H$. J. GROMACS: fast, flexible, and free // J. Comput. Chem.-2005.-26.-P. 1701-1718.

27. Guex N., Peitsch M. C. SWISS-MODEL and the Swiss-PdbViewer: An environment for comparative protein modeling // Electrophoresis. - 1997.-18.-P. 2714-2723.

28. Dubrovsky A. L., Savinskaya L. A., Kornelyuk A. I. Cloning and bacterial expression of the cytokine-like noncalalytic domain of bovine tyrosyl-tRNA synthetase // Biopolymers and Cell.-1998.-14, N 5.-P. 449-452.

29. Yaremchuk A., Kriklivyi I., Tukalo M., Cusack S. Class I tyrosyl-tRNA synthetase has a class II mode of cognate tRNA recognition // ЕMBO J.-2002.-21.-P. 3829-3840.

УДК $577.152 .611: 576.31$ Надійшла до редакції 21.08 .06 